\title{
THE GRAND JURY OF THE COUNTY OF NEW YORK
}

A Personal Experience

\author{
By George Haven Putnam, \\ New York.
}

I have served on the grand jury for something more than a third of a century, and during the later years of this period my service has usually been that of a foreman, as the judge and the district attorney always prefer to secure as foreman a juror who has had previous experience.

The institution of the grand jury goes back many centuries and is doubtless of Saxon origin. The earliest reference in English legal history to an "accusing body" apparently possessing the function of a grand jury, dates from the time of Henry III when each county had its own accusing body. In these earlier days, the conclusions of the jury were arrived at without any examination of witnesses; the presentments being based upon the personal information of the jurors. The twelve jurors (the number originally fixed) were sworn to "speak the truth;" and as they were all selected from the immediate vicinage where the events occurred or the conditions existed, their conclusions were assumed to be based upon direct knowledge of the facts. This requirement, which has not been essentially changed during the later centuries, constitutes the essential difference between the requirements for a grand jury and those that are, at least at this time, in force for the making up of the petty jury. The petty jurors, who have the responsibility for the final decision of the case, are, under the routine now in force, supposed to come to the trial with blank minds. It is assumed that all the knowledge that they secure of the matter at issue is to be obtained from the evidence and arguments presented in the court. They are, in fact, instructed by the court that their decision must be arrived at without consideration for, or the influence of, any other facts or information than have been presented in the course of the trial.

The grand jury as now constituted comprises, including the foremen, twenty-three members, and sixteen of these constitute a quorum. A true bill can be found, or a decision in regard to any matter 
at issue can be arrived at, only with the vote of not less than twelve jurors out of a quorum of not less than sixteen. The persons to serve as grand jurors are selected from the list of trial or petty jurors by a board comprising the presiding justice of the appellate division of the supreme court in the first department, the mayor, an associate justice and two justices of the court of general sessions. The commissioner of jurors serves as the clerk to said board and produces for their action the lists of jurors. This board also fills vacancies in the list. The persons selected are supposed to be men accepted as possessing standing and character in the community. It has proved possible, however, at times when the control of the city government was in the hands of Tammany Hall, to secure the acceptance in the list of grand jurors of men who could not properly so be described. It has been charged in fact that in years past men have been placed upon the grand jury for the particular purpose of protecting certain persons whose business and whose operations were opposed to the interests of the community and were likely to come under investigation.

The grand jury list or panel was for a number of years restricted to one thousand names; but in June, 1910, the panel was increased to twelve hundred. If one thousand jurors were required to carry on without hindrance or delay the business of the grand jury for the city of twenty-five years back, a panel of not less than three thousand names should be instituted in order to provide, without undue burden upon this special group of representative citizens, the necessary facilities for taking care of the routine business and to leave time free for the general supervision on the part of the jury of the operations of the city departments and for such special investigations into the work of the municipality and into alleged abuses as they may find occasion for. Twelve hundred men are not sufficient to give due attention to these two classes of responsibilities in a county containing more than three millions of people. During the past few years, it has been necessary to keep two grand juries in session each month, and not infrequently has there been requirement for the work of three juries sitting at the same time.

The service of a grand jury continues as a rule during the calendar month. but if at the end of the month the jury has on its hands any unfinished business, an investigation, for instance, in which a portion only of the witnesses have been heard, it is customary to 
hold the jury in session for such further time as may be required to complete each case that it has undertaken. The sessions of the jury are held daily, except Saturdays, but if a jury is continued in existence for the completion of unfinished business, it is not as a rule necessary during a second or third month to hold daily sessions.

Grand juries are sometimes called for the purpose of conducting a special investigation, and in that case they are held for periods extending from one month to five. The foreman is selected by the court after the twenty-three names have been drawn from the clerk's box. The foreman has authority to excuse certain members of the jury from day to day as long as he retains for the work of the day not less than the quorum of sixteen. The wise foreman will, however, refuse to excuse more than three men for any one day. It is difficult to ensure adequate attention for certain classes of business or to feel assured that justice has been done in important cases, unless at least twenty men out of the twenty-three have listened to the evidence. There is, of course, also always the chance that owing to temporary illness, or to some urgent requirement, one or more jurors may be called away in the course of the day's session.

The fee of two dollars is no greater than that accorded to the members of the petty jury, and the foreman, who is called upon to give a very much larger amount of time and skilled labor to the work, receives the same compensation as the other members. The foreman is expected to report earlier than the hour fixed for the session, in order to consider with the district attorney the business to be taken up. He is often called upon to remain after the session has closed, for the purpose of examining papers and of giving judgment in regard to witnesses to be called for the next day's session. The responsibility rests chiefly upon the foreman of initiating any special business to be taken up by the jury, and it is the foreman also who is expected as a rule to prepare the text of presentment or of reports on special investigations. A compensation of not less than $\$ 5$ a day would be in order if only to indicate the difference between the requirement made upon his time and attention as compared with what his associates are expected to give.

The grand jury sits as a part or division of the court to which it is attached, and by which it has in fact been constituted. This court is either the general sessions or the criminal division of the supreme court. Its room has, therefore, the character of a court room, and 
the foreman is expected to enforce the same dignity of procedure as is proper in a court when the presiding judge is present. Upon the foreman rests the responsibility of administering the oath or the affirmation to the witnesses, and the examination of the witnesses, except in the cases in which the foreman decides to place this in the hands of the district attorney, is conducted by the foreman. This routine calls for the active attention of the foreman during the whole of the session.

The business of the grand jury room in the county of New York is carried on quite largely in language other than in English. There are at this time from 70 to 100 different languages and dialects spoken within the county, and the proportion of trouble of one kind or another that comes upon our foreign citizens appears to be decidedly greater than that with which those of English or American birth are concerned. The grand jury has, therefore, subject to its call the interpreters attached to the court, men who are able, with a few exceptions, to compass the series of languages in which evidence is given. Many of these interpreters have served for a number of years, and their capacity and trustworthiness are vouched for by the court. Each interpreter must, before his statement can be accepted in a case, be sworn for the service of the month. There is risk that the interpreter may, instead of putting the question exactly as given by the foreman and of presenting a precise rendering of the reply of the witness, take the matter somewhat into his own hands. He has often talked with the witnesses before coming into the jury room, and he has his own definite opinion as to the nature of the case. This opinion may in the majority of cases be well founded, and I have, as foreman, not infrequently had occasion to express my obligation to the interpreter for suggesting a line of inquiry that had not occurred to me.

It is, however, undesirable to allow the interpreter to manage the case, and it is, of course, important also to bring home directly to the consciousness of each juror as far as possible the precise statements submitted by the witness. In past years, I have also had occasion to doubt the trustworthiness of interpreters who have been appointed under the recommendation of Tammany officials, and I have found that they were managing cases in a way that was not conducive to justice. I have made it a practice, therefore, as foreman, to utilize whenever possible the service of some member of the jury 
for questioning witnesses who could not make their statements in English. It is very seldom that a group of twenty-three New Yorkers does not include men who are conversant with German, French and Italian. In a city which contains one million Jews, we are also often able to secure from a juror the service of Yiddish. I have been able myself to manage inquiries in German when I was doubtful of the trustworthiness of the interpreter, and I always take pains in any case to check off the accuracy of the interpreter's reports in German and in French. I was puzzled once, however, with a language that was outside of the abilities of either the jury or of the court interpreters. A case was brought to us in which the person under charges and all the witnesses were reported as Chaldeans, that is to say they came from the lower Tigris. No gentleman on the jury would undertake Chaldean, and the several official interpreters gave up the task at once. I adjourned the case and sent to the police captain of the precinct where the Chaldean colony was situated, asking him to send up to the jury room a Chaldean who could speak English and for whose trustworthiness he could vouch. An hour later, my Chaldean citizen appeared and took charge of the case. I signed the indictment in due course and I only hope that it was the right person who was presented for trial. The Chaldean citizen, with his service first in the grand jury room and a fortnight later in court, was in position to clear off any old score that he might have had against a fellow countryman.

The time of a grand jury which has not been drawn for any special emergency is taken up chiefly with the routine business that comes in through the office of the district attorney. The complaints upon which the jury acts are in a majority of cases shaped before the magistrate or police justice. The district attorney takes note of the witnesses who have given testimony, or whose names have been specified in the proceedings before the magistrate, and he has these witnesses subpoenaed to appear before the grand jury. The responsibility rests upon the office of the district attorney of selecting and shaping the cases to be considered by the grand jury in such manner that witnesses shall not be called upon to give their time for more than the one day, usually the one morning. There are too many instances, however, owing either to incorrect calculation as to the time required for an individual case, or to heedlessness in which witnesses are called upon to sit in the witness room several 
days in succession before their testimony can be taken. A careful foreman will take pains from day to day to make a personal examination of the persons that are waiting in the witness room and will himself take action to prevent as far as possible the hardship of needless detentions. A foreman will sometimes hold a jury for fifteen or thirty minutes after the usual time of adjournment rather than to subject to a call for another day witnesses who have passed their whole morning in the witness room. The foreman will take pains to assure himself through reports from the office of the district attorney that the cases shall not be presented in the chronological order, but in the order of their actual urgency, and the urgent cases are, of course, those in which the persons under charges are also under arrest, and those in which the detention of witnesses (for instance, women with babies) involves hardships. The bail cases should always be held over until the jail cases have been disposed of.

Attention should also be given to securing promptly the evidence of witnesses who are in the house of detention, or who, not being residents of the city, have been held under subpoenas, when they want to get away to their homes or on their own business. It is sometimes advisable to take testimony from such witnesses in advance of the time when the district attorney is prepared to shape the case for final consideration. It is only necessary when the case finally comes up for completion, either to have the stenographer read the testimony given a day or two back, or for the foreman to recall to the jurors the substance of the same. Whenever the urgent jail cases, and the most important of the bail cases have been disposed of, so that there are no arrears on the calendar, the jury is free to give attention to the other division of its duties, name$l y$, the inspection of city institutions or an investigation into the work of city officials and the management of city departments.

The foreman sometimes finds it desirable, for this purpose, to arrange for a personal investigation of city institutions, such as the Tombs, the prison and asylums on Blackwell's and Ward's Islands, etc. It is sometimes wise to utilize for such investigations the entire body of the jury, while occasionally for some special investigation time can be saved by detailing one or more sub-committees upon whose report the jury can take action. Such investigations are sometimes made under the instructions of the court, but are often undertaken at the initiative of the jury itself. It is the duty 
of any individual juror to bring to the attention of the body any abuses of which he has personal knowledge, or which have been brought to his attention by responsible citizens, and if the time of the session permits, the jury will take prompt action on such a complaint. A juror bringing into the jury a complaint or grievance of which he has personal knowledge will be sworn as a witness. From time to time, as before mentioned, a jury is appointed with instructions in regard to specific investigations, and such a jury is freed from the routine business of jail cases or of bail cases.

A number of years back, I served as foreman of a jury which sat for five months, and which was charged with the duty of investigating the management of certain of the city departments. It was at the time when the organization known as the county democracy was under the direction of leaders like Judge Henry R. Beekman, who were endeavoring to overthrow the control by the Tammany leaders of the Democratic votes of the city. Among the men who were active in the county democracy was Hubert $O$. Thompson, who during the period in question secured office as head of the department of public works. My relations with Thompson in the committee rooms of the county democracy became somewhat strained when as foreman of the grand jury, I found occasion to take proceedings against his management of the public works. It was under Thompson that the city's money was squandered in the county court house, and it was chiefly as a result of malfeasance shown in connection with the county court house contracts that we finally found it necessary to frame an indictment against him. He skipped his bail shortly after and fled to the West Indies, and the committee rooms of the county democracy lost the value of the service of this particular reformer.

I may mention here as an illustration of the kind of evidence that was brought out in the history of the court house, the record of the contracts for painting the inside of the building. Thompson was under obligation to put up for competitive bidding all contracts for work amounting to more than $\$ 1,000$. He divided up the painting surface into sections so that the cost of each section need not exceed $\$ 1,000$. He went through the form of taking competing bids and awarded the contract for section number one to a pal of his own whose bid as recorded proved to be substantially lower than that of his competitors. The work on this section, including the 
charge for the scaffolding, was in fact done below cost. The second and the remaining sections were treated in the same manner, but in each case the other bidders found it necessary of course to include a charge for their scaffolding. The canny friend of Thompson whose scaffolding had been more than paid for in the compensation for sections one and two, was able to make a lower price for all the succeeding sections than was possible for his rivals, but even with this low price he got paid for his scaffolding almost as many times as there were sections in the building. It is not surprising that at the end of his operations in the court house he was willing to paint the commissioner's house without any charge.

The grand jurors find themselves not infrequently in doubt in regard to the credibility of a witness. The witness does not, at least in these preliminary proceedings, have to stand any crossexamination, and the jury should, of course, guard itself against the risk of basing an indictment upon evidence that does not impress them either as coming from a responsible person, or as being fairly well confirmed by corroboratory statements. I remember one case during the Thompson investigation in which an ex-employee of the department gave evidence which was decidedly important if true. I found after the witness had left the room that a number of the jurors had doubts as to his veracity. I noticed that the man wore a grand army button, and I said, "I think I can check the man's general truthfulness." I called him back and inquired about his army service.

"Where were you?"

"Chiefly in Virginia, sir."

"What battles were you in?"

"Well, sir, I was at Bull's Bluff, and in the battles of the peninsula, and all round."

"Who commanded at Bull's Bluff," I asked.

"Well, sir, Colonel Stone thought he commanded, but the gentleman on the other side did most of the commanding that day." It was evident to me that the fellow had been at Bull's Bluff, while his answer showed a capacity for discrimination and judgment that strengthened my belief in his testimony.

The jury depends for its legal advice upon the office of the district attorney, although it is also at liberty to make application for any special counsel to the judge of the court in which it has been 
impanelled. It is the practice of the district attorney to place at the disposal of the grand jury of the month one of his assistants who takes charge of routine business. In case, however, the month brings up cases varying in character, or if in the arrangement of the work of the office, the preliminary shaping of cases has been divided between several assistants, the jury may have a different legal adviser from day to day, or from hour to hour. The purpose is that as far as possible the case shall be shaped for the grand jury by the assistant who will have the personal responsibility for its management in the trial later. It is for the jury, and as a matter of routine for the foreman, to decide whether he will retain in his own hands the questioning of the witnesses or will ask the assistant district attorney to take charge of the matter. With hardly an exception, a suggestion on the part of the district attorney or his assistant that, having full knowledge of the history of the case, he can manage the questioning more effectively and with some saving of time, is at once accepted by the foreman. The foreman may, however, even then find it desirable, in order to be sure that the matter has been fully presented to the jury, to supplement the questions asked by the district attorney.

I had the opportunity of utilizing the grand jury for the defense of the reputation of my old commander, General Grant. The general had thought himself fortunate in being able to arrange to place his two sons in Wall street in association with a clever but unscrupulous financier, Ferdinand Ward, who was known at that time as "The young Napoleon of finance." In the firm of Grant and Ward thus constituted, the general himself became a special partner with an investment that represented practically all of his savings. The new firm carried on business for a year or two, and secured by subscriptions from various citizens, Wall street men and others, the use of a large amount of money for "investment" in a series of mythical "contracts." Ward represented to the investors that, through the influence of his special partner, the firm had been given certain special advantages for securing government contracts, but that it was, of course, not possible under the circumstances, to specify what the contracts were. The money thus secured was thrown away in South American speculations, and when the firm stopped business, the assets were practically nil.

I found that the city had money on deposit with the Marine 
Bank, the president of which, Fish, had taken an active part in Ward's speculative undertakings and had made to inquiring investors false statements about the deposits of Grant and Ward in the Marine Bank. This connection of the city depository with the firm gave the grand jury the opportunity of inquiring into its operations. I had the opportunity of examining the two sons of Grant who impressed me as somewhat obtuse men who had not shown proper intelligence in protecting the good name of their father. I also examined Ward at some length, and as he was at the time under conviction with a prison sentence and had nothing more to lose, his testimony was given with full frankness and with some sense of humor. He prided himself on his ability in inducing experienced men of business and officials like the city chamberlain to put money in his hands into a blind pool. I was able, as a result of his testimony and that of the two young Grants, and after an examination of the correspondence with the general, to make clear, in a presentment on the affairs of the firm, that General Grant had been entirely innocent of any knowledge of the mythical government contracts and that he had been kept carefully ignorant of the misuse that was being made of his name.

It is natural, under the routine that has grown up, that the office of the district attorney should assume the general direction of the work in the grand jury room; that is to say that the district attorney himself, or one of his assistants should determine from month to month and from day to day what work the jury should take up and what witnesses should be called. This routine is, however, merely a matter of convenience and does not mean that the district attorney has any authority to determine the action from the grand jury.

The jury, that is to say practically the foreman, sends for his legal adviser when he has need of him and if the jury decides to initiate certain business of its own, and is prepared to take the responsibility of completing such business without the aid and without the presence of the district attorney, it is within its rights in so acting.

I had the opportunity some years back of making a test of this matter of the relative authority of the grand jury on the one hand and the district attorney on the other. I was, as foreman, carrying on an investigation into the work of certain of the city author- 
ities, and more particularly, in regard to the relations between the police department and the law breakers who were securing police protection.

The notorious Devery was at that time chief of police and $G$. was the district attorney. Mr. G.'s leading assistants were Mr. U. and Mr. M. Among the law breaking concerns that we were investigating were the pool rooms, and at the head of the pool room business stood Mr. F. F. and Devery were brothers-in-law, and there were indications of a brotherly arrangement between the two, as a result of which it was very difficult to secure police evidence or police action against any of F.'s pool rooms.

I may recall here a noteworthy example of conflict of evidence. Two citizens who had volunteered evidence in connection with our investigation of the protection given by the police to law breakers, one of whom was a clergyman in good standing, reported that between the hours of two and three on the morning of a certain Sunday, they had found a notorious saloon in the tenderloin open and carrying on an active business. The saloon had an illuminated sign hung at right angles directly across the sidewalk a little above the head of passers. When the place was closed, this sign was dark. These men testified that noticing as they passed the illumination of the sign, they went into the saloon and saw drinking going on with men and with women present. One of them, in order to comply with the rather exacting provision of the law, took pains himself to purchase and to taste a glass of spirits. I examined later the roundsman, who was on beat in this street in the hour in question, the sergeant who with a fresh patrol relieved the roundsman, the captain of the district who had been carefully cautioned some little time before that the law was not being enforced and who reported that as a result of this caution he had made during the proper hours a personal inspection of the suspected places, and finally the inspector, who reported that he also had after caution been interested in going over the territory in this district. Roundsman, sergeant, captain, and inspector all swore that they had been on this block between the hours of two and three, and that the saloon complained of was dark and to all appearance fully closed. The grand jury reported charges against both inspector and captain. They were not removed but they were cautioned, and transferred to a district that was less "profitable" than the tenderloin. 
The jury came to the conclusion that the influence and the machinery of the district attorney's office were being utilized to protect the law breakers and to render difficult, if not impracticable, the collection of final or legal evidence against them. They believed there was a "leakage" in the district attorney's office of information in regard to our proceedings. I sent subpoenas direct (that is to say, not through the office of the district attorney) and I wrote letters direct to certain witnesses whose testimony was desired. I also received from certain public-spirited citizens proffers of testimony, and in a number of cases, these offers were connected with the request, or practically the condition, that they should not be called upon to testify in the presence of the district attorney, or any of his assistants. The risk of interference with a man's business or even with the comfort of his residence, if his name came on to the black list of Tammany, which meant, of course, the black list of the Tammany police in his own district, was serious.

On one morning early in the month, I was taking testimony from one of these witnesses who had volunteered information. The district attorney came into the room without first sending inquiry, or even without knocking, and he brought with him one of his assistants. My witness was one of those who wanted to keep his evidence, for the time at least, confidential, and I promptly sent him out of the room. I then explained to the district attorney that we were completing certain business that had been initiated by ourselves, and that we had not at that time requirement for the service of any one of our legal advisers. The district attorney replied, "I have a right to have knowledge of your proceedings, and for that purpose, I propose to remain while this evidence is being submitted."

The foreman: "We have decided, however, that we can do this business more effectively without your presence and I request you to withdraw."

The district attorney: "I decline. I have a right to be here."

The foreman: "We believe that you are in error in that contention, and that sitting here as a court, we have a right to control our own premises. I direct you to withdraw."

"I refuse," said the district attorney, "and you will find that you do not know what you are talking about."

Thereupon, I took the jury downstairs, put the question up to the court, and the district attorney and his assistant followed. "Your 
honor," I said, "the grand jury is carrying on certain investiga. tions of its own, and has made no requirement for the service of advisers from the office of the district attorney. The district attorney is interfering with the procedure of our business, and is, therefore, delaying our work. We understand that we have the authority to control our own premises, and that the district attorney is to come to us only when we have sent for him. We ask your honor to decide whether our understanding of our rights in this matter is correct."

"What has the district attorney to say?" inquired the court.

Mr. G. then went on to explain at some length how his ancestors had raised the first American flag on Manhattan Island. The court finally interrupted him. "That is not to the point, district attorney. I am waiting to hear your reply to the point raised by the foreman." Mr. G. then began a narrative as to how near he had been to being present at the battle of Gettysburg. The patience of the court became exhausted, and the district attorney was told to sit down. The court then delivered judgment in favor of the contention of the grand jury. "Gentlemen," he said in substance, "you are correct in your understanding. You occupy your premises as a division of this court and you have a right to control your courtroom and your time as, under the provisions of the law, seems to you best. If you are prepared to take the responsibility of initiating work and of arriving at decisions without the counsel of your legal adviser, you are within your rights in so doing."

We returned to our room, and in the course of the following weeks made good progress with our investigations. One conclusion at which we arrived was that the district attorney's office was being used to protect wrong-doers and to interfere with the operations of justice and I made a presentment to such effect. The result of such presentment, after two sets of investigations by the governor of the state (at that time Theodore Roosevelt), was that Mr. G. was removed from office. The governor directed me to come to breakfast with him so that he might secure the full particulars on which our charges were based. He took pains to report to me later that he never could have succeeded in getting rid of a district attorney, whose office represented the worst of the Tammany methods, if it had not been for the information contained in our presentment. I understood that the issue had not before been raised in the county of 
New York, and that the precedent that had been thus established was of importance. A week or two later I received a letter from a foreman of a grand jury sitting in Providence asking for the details of our action. He wrote again at the end of the month that their jury had been conducting a similar municipal investigation, and that they had been able to bring it to a successful conclusion only when, under the precedent established by us, they had gotten rid of their district attorney. The district attorney took the ground that the presentment of the grand jury was an impertinence in itself, and that the shaping of such a presentment to the court was outside of the function and the authority of the jury. He made application to the court to have the presentment expunged from the records of the court. This application came up in the month succeeding the work of our grand jury, and was submitted to a judge who had been elected on the Tammany ticket and who was supposed to be not out of sympathy with the policy of protecting Tammany officials.

The late Wheeler H. Peckham, a leader of the bar who was always ready to render unselfish service to the community, volunteered to defend the action of the grand jury. He explained to me that there was no precedent for such an application as had been made by the district attorney, and he presented to the court a carefully prepared argument to the effect that the grand jury had acted within its rights and that the presentment properly belonged on the records of the court. The judge decided in favor of the application of the district attorney, and the presentment was, I believe, duly "expunged from the records." One result, however, of the publicity given to the matter was that the purpose and character of the presentment were brought to the attention of the press in the city and throughout the state, and the essential portions of it were brought into print in a large number of papers. If it had not been for the application of the district attorney, very few citizens would have known that such a presentment had been made.

During the rest of the month, our relations with the office of the district attorney were naturally strained, and I found it advisable to take the counsel that I needed from the judge. I was still in perplexity in regard to my subpoenas and correspondence, because in so far as the letters were written by the stenographer assigned to our room, information about them was promptly given to the 
district attorney by whom the stenographer had been appointed. I finally took one of my daughters, who was a clever stenographer, to the judge's house in the evening and had her sworn in as a special stenographer of the court for that month. From the rooms of the grand jury, I took home notes, on the basis of which I dictated letters through the evening. My girl typewrote the letters, sitting up for the purpose until late hours; and in the morning I took down the typewritten sheets and after they had been approved by the grand jury, I signed and dispatched them. We succeeded in getting in this way valuable evidence which would never have come to us through the district attorney's office, and as a result of our action a number of the police officials were brought to trial. One of the sheets typewritten by my daughter came into the hands of the district attorney, and he thought that he had then secured a real ground of complaint against the foreman. I was summoned to court to meet the charge submitted by the district attorney that I had broken my oath and had permitted the business of the grand jury room to come to the knowledge of some outside party. As evidence of this charge, one of the letters typewritten by my daughter was held up in court with the word that the typewriting had not been done by the official stenographer. "What have you to say?" asked the court of the foreman. "Your honor will recall," I replied, "that early in the month your honor swore in for the use of the present grand jury a special stenographer, and I am able to state that no papers or correspondence connected with the work of the grand jury have been in the hands of any but the regular stenographer and the special stenographer appointed by the court." The district attorney was taken aback and was very much annoyed. At the end of the session, the jurors gave me a dinner and a piece of silver, and they sent to the special stenographer, whom they had never seen, but who had, as they realized, rendered good service to them and to the city, another piece of plate filled with roses.

Shortly after the completion of the work of this particular jury, I was called upon for service in the committee of fifteen, the operations of which extended over two years.

The information secured in my experience on the special investigations of the grand jury was of immediate service in connection with similar work undertaken by the committee of fifteen, a committee which came into existence in 1900, and the operations of which con- 
tinued for two years. This committee arrived at a series of conclusions in regard to the relations between the police and the other municipal authorities and the law breakers. It was clear to us that the Tammany officials had been interested in securing enactment in Albany of strenuous laws for the suppression of bad houses and of gambling and pool rooms, and for the restriction of the sale of liquor, for the purpose of being in a position to sell at substantial prices the privilege of breaking the prohibitions of such statutes. We estimated that in the year 1900 not less than $\$ 2,500,000$ had been collected through the police officials from the managers of bad houses, of gambling houses, of pool rooms, and from the dealers in liquor as consideration for "protection" by the police. Each person, roundsman, sergeant, captain, and inspector, through whose hands the collections went, was entitled to retain as commission some portion of the dirty money. I had occasion later, when Mr. McClellan was trying to secure a reëlection, to make a summary, printed in the New York Times, of the bad appointments for which during his first term he had been responsible. I pointed out that the man he had appointed as chief of police had been shown up by the Lexow committee as having received while inspector weekly payments from bad houses. Instead of demanding an investigation, the inspector had promptly resigned from the force. His return as chief of police constituted, as I pointed out, an insult to the city, and naturally tended to the demoralization of men for whose discipline he was responsible. The result of my publication was a suit for libel brought by the official in question for damages of $\$ 50,000$. It took me three years to bring this suit to trial, and the plaintiff offered to compromise for $\$ 25,000$, for $\$ 10,000$ for $\$ 5,000$, and finally for $\$ 1,000$. I refused to make any payment which would imply that my charges had not been well-founded. I finally succeeded in getting the suit brought to trial, with the result that the jury gave a verdict for the defendant, but the proceedings cost me something over $\$ 1,200$. The information upon which the investigations of the Lexow committee were based was in large part the result of the presentment of the preceding grand juries.

In our undertaking to trace the relations between the police and crime, and particularly to break up the operations of the infamous cadet gang, we found ourselves from time to time confronted by one of Mr. G.'s chief assistants. I had here corroboratory evidence of 
the relations of the office of the district attorney with the law breakers, with whose business we had been interfering. Fortunately, conditions have very much improved since the time, some twenty years back, of this special jury experience. I doubt whether it would have been possible at any time since that date for the law breakers of the city to secure any help or protection from the office of the district attorney, and during the past ten years, and particularly the last four years, the operations of this office have been managed with exceptional efficiency, as well on the ground of good judgment as of initiative and courage.

$\mathrm{My}$ own experience gives me ground for the following recommendations in regard to the work of the grand jury:

1. The panel should be increased promptly to not less than two thousand, and preferably twenty-five hundred names.

2. More thorough supervision should be given to the examination of the men selected for the list with reference not only to the fact that they are decent citizens, but that they have in their careers given evidence of such general capacity as would make their judgment serviceable in the grand jury room. There are still examples, although it is fair to say that at this date there are comparatively few, of men who under some personal influence have been included in the grand jury list, whose capacities are not up to the requirements of the post. Some of these men, through stupidity, and others through perversity, interfere with and delay the proceedings.

During the operations of the committee of fifteen, we had occasion to make a raid early Sunday morning on a notorious house in a down-town police district. The owner of the house was, as we found a little later, a member of the grand jury at that time in session, before which jury our charges against the arrested man were to be submitted. Under the report of the committee, the person in question was dropped from the grand jury list.

3. There should be a reshaping of the business to which the grand jury is called upon to give its attention, and it should be freed from the necessity of passing upon a long series of cases which do not require the judgment of twenty-three citizens. In London, county magistrates, or police justices, have the final disposition of a large number of the smaller issues which, under the routine in New York, after taking time in the magistrate's court with witnesses and officials, call for further time in the grand jury room from the same 
witnesses and from twenty-three citizens before being finally passed upon in the court of general sessions, with the requirement for a third service from the same witnesses, and with the expenditure of valuable time on the part of more officials.

A body which has in its hands the authority to investigate into the workings of the city government and to call before it for the purpose the highest city officials, and which in criminal proceedings is charged with the responsibility of decisions in the most serious class of crimes, ought not to be called upon to give time (the time of twentythree men) to passing upon a quarrel between a couple of intoxicated men, or to reaffirm a fact which has already been established by satisfactory evidence that a citizen had a pistol in his pocket, or to take action in a long number of simple cases in which the party under charges has already pleaded guilty.

A number of these cases, particularly the smaller ones, such as the enforcement of the laws against concealed weapons, ought to be finally passed upon, without appeal, by the police justice. The cases, excepting those of the highest crime (in which there is occasional risk of an hysterical and untrustworthy confession), under which the defendant pleads guilty, may properly go directly to the court. If in criminal proceedings, the grand jury had to do only with cases of serious misdemeanor or with cases of possibly smaller moment, but in which the evidence was complex, the hours so saved could be well expended in a closer supervision of the work of the city departments and of the operations of city officials, and in carefully considered recommendations for the improvement of municipal methods and the removal of abuses of one kind or another.

The grand jury is, in my judgment, a most valuable institution. It constitutes the only means by which citizens who are not in office can bring to bear directly, and with a measure of authority, their criticisms or inquiries concerning the methods of action of the officials that they have put into office and of the government the cost of which they are sustaining. While the term is but brief (as a rule it does not exceed thirty days), during such term the twenty-three men represent directly the highest authority of the citizens of the community and their authority and responsibility can be, and has been, exercised in the defense of the rights of citizens and in furtherance of the interests of the city. 
The difficulty that suggestions or recommendations, however valuable, arrived at by one grand jury are apt to be overlooked or to fail to secure adequate attention on the part of succeeding juries, has in the past prevented certain investigations from being initiated which could not be completed within the time available. The attempt is now being made to remove this difficulty. Certain publicspirited members of recent grand juries have come together in a continuing committee, which, while possessing no official authority, has the power and the opportunities that belong to direct knowledge and experience, and to unselfish public interest. This committee is in a position to impress upon successive grand juries and upon the community the importance of one undertaking or another which may be put in train and for the proper carrying out of which continuity of action is important. Such continuing committee, made up of active and public-spirited representatives from the grand jury panel, can render intelligent service and can do much to strengthen the efficiency of the work of successive juries. 